\title{
Key attributes of successful innovation strategy in the global market
}

\author{
Pavol Kral ${ }^{1, *}$, Katarina Janoskova ${ }^{1}$ \\ ${ }^{1}$ University of Zilina, Faculty of Operation and Economics of Transport and Communications, \\ Department of Economics, Univerzitna 8215/1, 01026 Zilina, Slovak Republic
}

\begin{abstract}
.
Research background: At the current global market environment, innovations are perceived as a driving force of economic development and a basic prerequisite for competitiveness. Worldwide-level discussions are related to topics regarding knowledge-based economy development, financing and innovation management mechanisms, research and development support, international cooperation, all supporting the fact that innovations are a significant prerequisite to fulfil goals of sustainable development of the society

Purpose of the article: The primary goal of the paper is to define the key dimensions of a successful innovation strategy ensuring competitiveness and growth in a global market. These are reference characteristics enabling comprehensive consideration of the conditions of the external and internal environment in which the innovation strategy will be formed and implemented. The issues in question determinants will be investigated and evaluated at theoretical level, then practical, scientific and application approach as well as management aspect.

Methods: Ambition of the authors is to use theoretical knowledge, results of systematic research, experience and publication activity outputs to create an informative scientific platform dedicated to elimination of "white areas" in the field of innovation strategies (innovation management) with possibility of implementation in company practice. There was apply several suitable methods of scientific research (formal logics methods: analysis, synthesis, deduction, induction, comparison, abstraction).

Findings \& Value added: There is a potential for paper and research outputs to be applied in management practice at the level of national or global market.
\end{abstract}

Keywords: innovation strategy; innovations; global market

JEL Classification: $O 31 ; O 32 ; F 60$

${ }^{*}$ Corresponding author: pavol.kral@,fpedas.uniza.sk 


\section{Introduction}

There is no doubt that innovation is an important source of economic growth [1]. Innovation is today considered of considerable importance for firms, as levels of competition are swiftly rising and production methods are rapidly improving. Organisations need to have new ideas that lead to new products, processes and programmes, and to develop new technologies that improve their performance and competitiveness and lead to products that set them apart from their competitors. [2]

Every innovation is about creating new value customers are willing to use and pay for. Companies usually gain competitive advantage, primarily, by the creation and commercialization of various innovations types. The innovation is one of the main aims within the management strategy for a large amount of organizations currently.

It is increasingly difficult to identify current sources of company position in the global market in the current globalized economy, which is facing economic turbulence, shorter or longer economic crises, new inventions, and Information and Communication Technologies phenomena [3].

There are a few definitions of an innovation strategy in the literature. Innovation strategy is innovative direction of company approach to the choice of objectives, methods and ways to fully utilize and develop the innovative potential of the enterprise. This is the direction given of its boundary, which determines the potential of innovative strategies [4]. Kovac [5] sees innovation as a strategy for determining long-term fundamental business objectives and determines the activities and resources for achieving these goals. Orientation objectives are focused on timely response to changes in signalling of need of innovations. According to him the innovation strategy must be based on variation, long term, systematism, the time factor and the concentration of resources and activities. An innovation strategy can be incrementalist, functional, predetermined plan governing the allocation of resource to different types of innovations in order to achieve a company's overall corporate strategic objectives and a decision framework guiding a company about when and how it should selectively abandon the past and/or change its corporate strategy and objectives in order to focus on the business of the future [6]. Innovation strategy is defined as the sum of strategic choices a firm makes regarding its innovation activity. Innovation goals (ends) are not included - only means. Innovation strategy is considered a firm wide, cross-functional meta-strategy [7]. Innovation strategies are potential actions that require decisions made by the management and human resources.

Identification of factors determining the innovative activity of enterprises is one of the basic directions of research on growth and economic development. This task is extremely complex, because it is conditioned not only by the singular internal properties of enterprises, but also by the aspects regarding the socio-economic environment [8].

\section{Methods}

The basic research method was the analysis of available resources dealing with the issue of innovation strategies. The most relevant variables of each selected paper were identified, in terms of not only the concepts of the innovation strategy or its theoretical analysis but also its formulation and practical implementation. Based on the results of the analysis were defined key attributes of successful innovation strategy.

For several years now, at the organizational level there has been growing interest in comprehending the innovation strategy characteristics, particularly how it is materialized in varied enterprises - in other words, how the strategy is formulated and implemented [9]. For example Schilling [10], has developed various proposals in order to elaborate a sort of the innovation strategy generic "profile". Teece and Pisano [11] distinguish three elements of a 
corporate innovation strategy: competitive national positioning, technological trajectories, and organizational and managerial processes.

Schilling [10] establishes methodology approach to the concept of the successful innovation strategy (formulate and implement) within the company. He divided this process into phases: formulation of the innovation strategy, $\mathrm{R}+\mathrm{D}$ project map, collaborative forms, intellectual property and digital rights mechanisms. The phases of the innovation strategy implementation are: organizational structure, new product/service management methodology, development team structure, and strategy deployment. These formulation and implementation phases are shown in figure 1 .

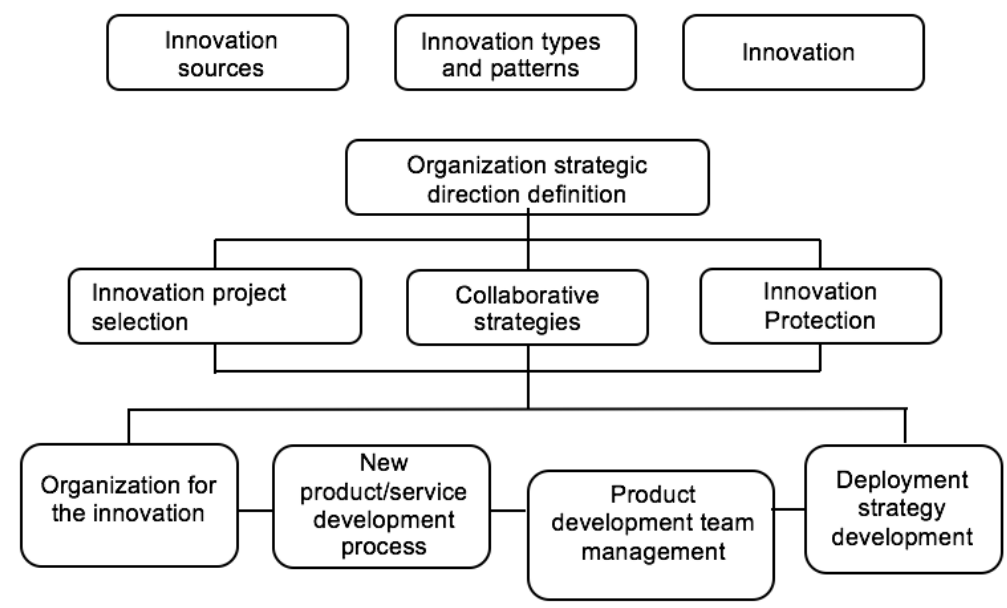

Fig. 1. Phases - the innovation strategy formulation and implementation Source: [9]

Shell [12] states that innovation strategy is applied when opportunities are found or created: by perceiving consumer's needs, through the generalization of solutions to a specific problem, or when strategies are enabled by predictions based on opportunities derived from cost reduction on technology, the arrival of new applications generated from emergent technologies, the intersection of new technologies, or the efficient search for opportunities and solutions to perceived issues, by means of an extensive research and technological development program.

\section{Results and discussion}

Pelser [13] conducted interesting study where he analysed 8 innovation strategy variables in 89 enterprises. The purpose of the considered variables was: to evaluate innovation management efficiency, to have a strategy for innovation management and market innovation, to evaluate market innovation efficiency, to attain a product innovation strategy, to assess product and process innovation efficiency, and to possess a strategy for process innovation.

The basic components of an innovation strategy are presented in Figure 1. 9 components have been identified crucial for an innovation strategy in order for the strategy to fulfil the roles and align with the comprehensive definition defined. 


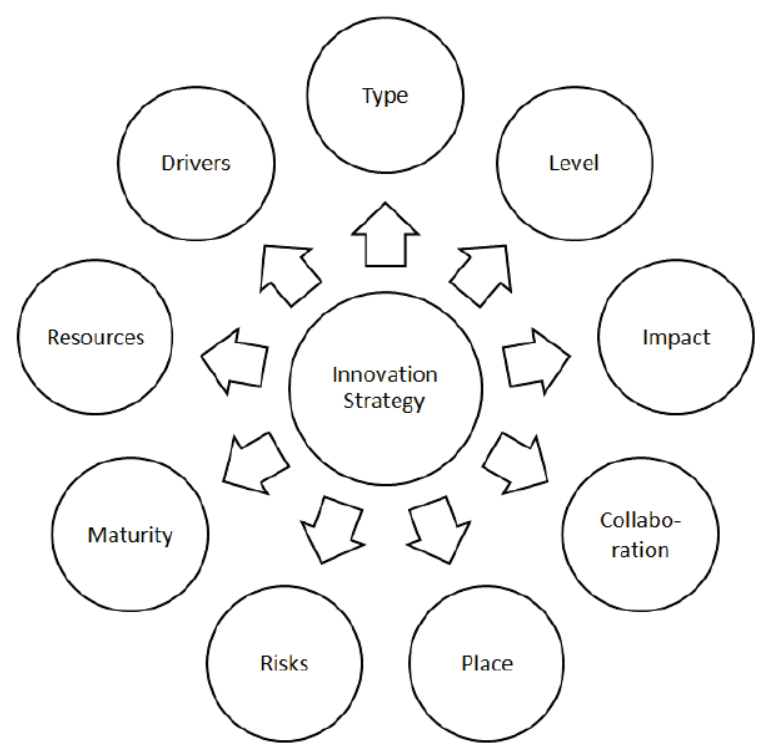

Fig. 1. 9 Components of an innovation strategy Source: [6]

There is a big range of literature and studies that shows that sucessful innovation strategy has a direct impact on performance, competitive advantage and a companie's success in domestic and international markets.

Lendel and Varmus [4] are convinced that dh innovation strategy is significantly affected by five basic (core) elements. It can be entered in the form of the functions of five variables that affect the implementation and realization of innovative strategies:

$$
I_{S}=f\left(I_{m}, I_{P S}, L_{M}, P_{K}, O_{\check{S}}\right)
$$

where:

$I_{S} \quad$ - innovation strategy

$I_{m} \quad$ - innovation management

$I_{P S} \quad$ - innovative potential of strategy

$L_{M} \quad$ - later thinking

$P_{K} \quad$ - pro-innovation climate

$O_{\check{S}} \quad$ - organizational structure

Business success in the global market is also dependent on management, its goals, and strategic management activities. The strategic objectives of the firm are that there must be the realization of innovative activities with the subsequent creation of innovations, as well as the cultivation of social capital that has a direct and indirect impact on the quality of innovative processes as well as on innovation performance [14].

Zartha et al. [9] present a methodology that creates an innovation strategy diagnostic tool within productive sector organizations based on the analysis of scientific articles, patents, $\mathrm{PhD}$ theses, and technical documentation related to the topic. Their analysis was complemented with application of the surveys to the $\mathrm{R}+\mathrm{D}+\mathrm{i}$ experts in order to obtain knowledge on the prioritized issues, necessities and opportunities of the innovation strategy as well as the main innovation strategy input and output, with the purpose of identifying the most significant variables, thus designing a diagnostics of the entrepreneurial innovation strategy. 
Freeman [15] defined 6 enterprise strategies for the innovation process: offensive innovative strategy, defensive innovative strategy, imitative strategy, dependent strategy, traditional strategy, and niche or opportunistic strategy.

The key attributes of a successful innovation strategy can be considered:

- realistic goals - to have clear goals, realistic, aspirational

- clear and compelling purpose in innovations - clear innovation strategy

- objective analysis of environment - objective and unbiased understanding of external and internal environment

- clear choices - to do too many things makes it difficult to do any of them well

- urgency - not postpone duties and activities until later

- transparency - embrance the strategic innnovation plan as own plan

- monitoring, measurement, control and feedback - monitoring of plan progress, mesure outputs and outcomes, obtain feedback

- add real value of innovation

- appropriate metrics - global outcome measures like ROI indicate whether a strategy is working, but key performance drivers, tailored to innovation strategy, are a better indication

- passion - heart of every great innovation strategy (soft concept)

As a result of failing to innovate, the enterprise loses its ability to compete because it insufficiently invests in non-material areas of business. Such areas include, in particular, product and process innovation, investment in employees' skills, motivation and customer satisfaction. Investing in new products, new techniques, and practices worsens the company's short-term financial results. Also, investments in human capital and employee training negatively impact short-term financial results. However, this does not mean that the enterprise will get into trouble because of that. In the long run, this investment will bring profits and increase the value of the business -which is the main objective of the business owners after all [16].

According Roliak [17] the innovation strategy, innovations and innovative processes play a decisive role in the matter of acquiring and maintaining strengths of a company in a battle with the competition. Currently, innovations and the attitude towards innovations to a great extent determine the positions of big and small companies alike, including start-ups. Management of innovative transformations provides for a certain order in choosing and implementing the innovation strategy: starting with determining the aim and ending with practical achievement of the aim. Implementation of the innovation strategy is supplemented with transforming and renewing the content and use of various resources and with redesigning the business processes, subject to novelties in managing and forming the organisational structure of the company. These transformations imply a transition from the innovation strategy to implementation of the innovation project. Upon deciding on all issues related to investments of the innovation project, it acquires the final shape in a form of an innovation programme.

\section{Conclusion}

More than 70 percent of strategic plans fail. From time to time, innovation isn't always getting success [18]. As a result of failing to innovate, the enterprise loses its ability to compete because it insufficiently invests in non-material areas of business. Such areas include, in particular, product and process innovation, investment in employees' skills, motivation and customer satisfaction. Investing in new products, new techniques, and practices worsens the company's short-term financial results. However, this does not mean 
that the enterprise will get into trouble because of that. In the long run, this investment will bring profits and increase the value of the business [19].

Business management should be able to define determinants that fundamentally influence the innovation activity of business. Innovation leaders are influenced by the same set of determinants that allow them to maintain their position in the market. Identifying these determinants is a key source of knowledge for defining or adjusting corporate strategies, enabling sustainable benefits [20].

Authors ambition was using theoretical knowledge, results of systematic research, experience and publication activity outputs to create an informative scientific platform dedicated to elimination of "white areas" in the field of innovation strategies (innovation management) with possibility of implementation in company practice.

The choice and implementation of the innovation strategy depends on the situation of the innovation potential. The strategy must become an action in order to achieve the innovation success. High complexity innovation strategies can resist imitation attempts. Approach based on the innovation strategy complexity raises a barrier against imitation. Such a barrier depends on the number of decisions that comprises the strategy and the level of interaction between decisions.

The contribution is an output of the project VEGA 1/0619/20 Fundamental research of quantitative and qualitative determinants of enterprise innovation potential and innovation performance in relation to increasing its competitiveness.

\section{References}

1. Jakimowicz, A., Rzeczkowski, D. (2019). Do barriers to innovation impact changes in innovation activities of firms during business cycle? The effect of the Polish green island. Equilibrium. Quarterly Journal of Economics and Economic Policy, 14(4), 631676.

2. Gallego-Álvarez, I., Pucheta-Martínez, M.C. (2020). Hofstede's cultural dimensions and $\mathrm{R} \& \mathrm{D}$ intensity as an innovation strategy: a view from different institutional contexts. Eurasian Business review, early access.

3. D'Aveni, R.A., Dagnino, G.B., Smith, K.G. (2010). The age of temporary advantage. Strategic Management Journal, 31(13), 1371-1385.

4. Lendel, V., Varmus, M. (2011). Creation and implementation of the innovation strategy in the enterprise. Economics and Managemet, 16, 819-825.

5. Kováč, M. (2007). Tvorba a riadenie inovácií. Košice: TU v Košiciach.

6. Karz, B.R., Preez, N.D., Schutte, C.S. (2010). Definiton and role of innovation Strategy. Conference proceedings SAIIE 24 (pp. 60-74). Glenburn Lodge, Gauteng.

7. Strecker, N. (2009). Innovation Strategy and Firm Performance: An Empirical Study of Publicly Listed Firms. Gabler Verlag.

8. Wziątek-Kubiak, A., Balcerowicz, E., Pęczkowski, M. (2013). Differentiation of innovation strategies of manufacturing firms in the new member states: cluster analysis on firm level data. Argumenta Oeconomica, 31(2), 117-149.

9. Zartha, J.W., Montes, H.J.M., Vargas, M.E.E., Velez, E.E., Hoyos, C.J.L., Hernandez, Z.R., Novikova, O. (2016). Innovaton strategy. Revista Espacios, 37(24).

10. Schilling, M. (2013). Dirección estratégica de la innovación tecnológica. McGrawHill.

11. Teece, D. J., Pisano, G., Shuen, A. (1997). Dynamic capabilities and strategic management. Strategic Management Journal, 18(7), 509-533. 
12. Shell, C. (2002). Estrategias de negociación y comercialización de tecnología. En el marco del diplomado en convenio con IC2, Tecnológico de Monterrey, Universidad Pontificia Bolivariana y Colciencias.

13. Pelser, T. (2014). The Affect of Innovation Strategies and their Connect to Company Performance. Mediterranean Journal of Social Sciences, 5(9), 60-68.

14. Porter, M.E., Ketels, C.H. (2003). UK competitiveness: Moving to the next stage. DTI Econ. Pap. 3.

15. Freeman, C. (1974). La Teoría Económica de la Innovación Industrial. Madrid: Alianza Universitaria.

16. Dobrovič, J., Urbański, M., Gallo, P., Benková, E., Čabinová, V. (2018). Balanced scorecard concept as a tool of strategic management and its usage in the construction industry. Polish Journal of Management Studies, 18(2), 59 - 72.

17. Roliak, Y.A. (2013). A complex Approach to Evaluating the Innovation Strategy of a Company to Determine its Investment Attractiveness. In M. Ozsahin (Eds.), Proceedings of 9th International Strategic Management (pp. 562-571). Amsterdam: Elsevier Science BV.

18. Franklin, C. (2003). Why Innovation Fails. Spiro Press.

19. Dobrovič, J., Kmeco, L., Gallo, P., Gallo, P. Jr. (2019). Implications of the Model EFQM as a Strategic Management Tool in Practice: A Case of Slovak Tourism Sector, Journal of Tourism and Services, 10(18), 47-62.

20. Striteska, M. K., Prokop, V. (2020). Dynamic Innovation Strategy Model in Practice of Innovation Leaders and Followers in CEE Countries-A Prerequisite for Building Innovative Ecosystems. Sustainability, 12(9), art. no. 3918. 